\title{
Factors Affecting the Quality of Life in Climacteric Women in Manisa Region
}

\author{
Manisa Bölgesinde Yaşayan Klimakterik Dönem Kadınlarında Yaşam Kalitesini Etkileyen Faktörler
}

\author{
Ümit İNCEBOZ, ${ }^{1}$ Hülya DEMIRCİ, Ferda ÖZBAŞARAN, ${ }^{2}$ Ayden ÇOBAN, Sevgi NEHİR \\ Department of Nursing, Manisa School of Health, ${ }^{1}$ Department of Obstetrics, Medical Faculty of Celal Bayar University, Manisa; \\ ${ }^{2}$ Department of Nursing, Balkesir School of Health, Balkesir
}

Submitted / Başvuru tarihi: 23.09.2008 Accepted / Kabul tarihi: 14.11.2008

Objectives: To determine the factors affecting the severity of menopausal symptoms and the quality of life among women living in Manisa, a western city of Turkey.

Patients and Methods: After statistical estimation of the sample size reflecting the whole population, 268 climacteric women (mean age $50.7 \pm 6.6$ years; range 40 to 60 years) with menopausal symptoms were investigated by sociodemographic questionnaire, menopause rating scale (MRS), and Quality of Life Scale (WHOQOL-BREF-TR) in Celal Bayar University Hospital.

Results: Almost $1 / 3$ of women had no knowledge on menopause. The MRS scores of women were inversely correlated with Physical Health, Psychological well-being, Social Relationship domains of quality of life. Educational level, menopausal knowledge, participation in decision-making in the family and economic status positively affected most domains of quality of life, whereas being married and having high BMI scores had negative effects.

Conclusion: In climacteric women, quality of life was negatively affected by the severity of menopausal symptoms, low education level, limited menopausal knowledge, and being overweight.

Key words: Quality of life; menopause; climacteric; MRS; WHOQOL-BREF.
Amaç: Bu çalışmadaki amacımız, Manisa ve çevresinde yaşayan klimakterik dönemdeki kadınlarda yaşam kalitesi ve menopoza ilişkin semptomların şiddetine etki eden faktörleri belirlemektir.

Hastalar ve Yöntemler: Araştırmanın örneklemi evreni belli örneklem seçim yöntemi ile $268 \mathrm{kli}-$ makterik dönem kadın (ort. yaş $50.7 \pm 6.6$; dağılım 40-60) olarak belirlendi. Verilerin toplanmasında sosyo-demografik soruların bulunduğu anket formu, Menopoz Semptomlarını Değerlendirme Ölçeği (MRS) ve Yaşam Kalitesi Ölçeği (WHOQOLBREF-TR) kullanıldı.

Bulgular: Kadınların yaklaşık 1/3'ü menopoza ilişkin bilgilerinin olmadığını belirttiler. MRS skoru ile yaşam kalitesi alan puanları karşılaştırıldığında, MRS skoru ile bedensel, ruhsal ve sosyal alanlarda istatistiksel olarak anlamlı fark bulundu. Kadınların eğitim durumu, menopoza ilişkin bilgileri, ailedeki kararlara katılma ve ekonomik durumu yaşam kalitelerini olumlu etkilemekte, evli ve yüksek vücut kitle indeksi skoru olan kadınlarda ise yaşam kalitesi olumsuz etkilenmekte idi.

Sonuç: Klimakterik dönemdeki kadınlarda, menopozal semptomların şiddeti, eğitim düzeylerinin düşüklüğü, menopoza ilişkin bilgilerin sınırlı olması ve kilolu olunması yaşam kalitesini olumsuz etkilemektedir.

Anahtar sözcükler: Yaşam kalitesi; menopoz; klimakterik; MRS; WHOQOL-BREF.

Presented at the 8th Uludağ Winter Congress on Obstetrics and Gynecology, January 17-21, 2007, Bursa, Turkey (8. Uludağ Jinekoloji ve Obstetri K/ş Kongresi'nde sunulmuştur, 17-21 Ocak 2007, Bursa).

Correspondence (Illetişim adresi): Dr. Ayden Çoban. Adnan Menderes Üniversitesi, Aydın Sağlık Yüksekokulu, Ebelik Bölümü, 09100 Aydın.

Tel: 0256 - 2138866 Fax (Faks): 0256 - 2124219 e-mail (e-posta): ayden.coban@adu.edu.tr

(๑) Trakya Üniversitesi Tip Fakültesi Dergisi. Ekin Tıbbi Yayıncllık tarafından basılıışıtr. Her hakkı saklıdır.

○ Medical Journal of Trakya University. Published by Ekin Medical Publishing. All rights reserved. 
Thousands of years ago, Roman philosopher, Lucius Annaeus Seneca (c. 4 B.C. - A.D. 65) demonstrated importance of quality of life by saying that "It is quality rather than quantity that matters". The quality of life in postmenopausal period has drawn much attention especially in recent years, since almost one third of the life of a woman is being spent after menopause.

The climacteric period is an important sequence because especially vasomotor complaints and other individual factors gather and show an added impact on quality of life. As recently underlined by Utian,,$^{[1]}$ not only the menopausal changes but also "physical, emotional, and social functioning or role limitations" have to be taken into account in terms of the quality of life of a person.

Sociocultural differences should also be considered and validations of scales should be performed before using these scales for the evaluation of quality of life in a certain population.

We aimed to investigate the factors that affect the quality of life of climacteric women living in Manisa region by using generic and specific scales both of which have been validated in Turkish population.

\section{PATIENTS AND METHODS}

This study was performed in Celal Bayar University Education and Research Hospital Obstetrics and Gynecology Clinic after obtaining the approval of Local Human Research Ethics Committee and written consent from the patients.

\section{Sample Selection}

The sample size of this investigation $(\mathrm{n}=310)$ was statistically estimated so that the results can reflect the whole population. The universe was composed of 1346 women applied to menopause clinic between September 1, 2004 and August 30, 2005. The sample size of the study was calculated according to the formula of "sampling for the known universe" (calculated size; $\mathrm{n}=310$ ). Two hundred sixty-eight women (mean age $50.7 \pm 6.6$ years; range 40 to 60 years) with menopausal symptoms and high FSH levels (>40IU/L) who applied to menopause clinic from September 1, 2005 to September 30, 2006 accepted to participate in the study $(86 \%)$. Women who reported still having menstrual periods were classified as perimenopausal. Menopausal status was defined as one year amenorrhea with high serum FSH measurements ( $>40 \mathrm{IU} / \mathrm{L}$ ). Patients on hormone therapy or selective serotonin reuptake inhibitors (SSRI)/serotonin and norepinephrine reuptake inhibitors (SNRI) were not included in the study.

\section{Data Collection}

We have used three tools for data collection; 1) Questionnaire (40 questions on sociodemographic features, obstetric history, menopausal status, knowledge about menopause, medications), 2) Menopausal rating scale (MRS), 3) WHOQOL-BREF-TR. Data were collected by face-to-face interview.

\section{Menopause Rating Scale (MRS) Questionnaire}

MRS was initially developed to measure the severity of the menopausal symptoms by rating the symptoms in early $1990^{\prime} \mathrm{s} \mathrm{s}^{[2]}$ The information on development and standardization of the scale were previously published..$^{[3]}$

Table 1. Sociodemographic characteristics of the cases

\begin{tabular}{|c|c|c|}
\hline Characteristics & $\mathrm{n}$ & $\%$ \\
\hline \multicolumn{3}{|l|}{ Age $(n=268)$} \\
\hline $40-47$ & 83 & 31 \\
\hline $48-55$ & 132 & 49.2 \\
\hline$>55$ & 53 & 19.8 \\
\hline \multicolumn{3}{|l|}{ Mean age: $50.7 \pm 6.6$} \\
\hline \multicolumn{3}{|l|}{ Educational level (n=247) } \\
\hline No formal education & 46 & 17.7 \\
\hline Primary school & 140 & 52.2 \\
\hline High school & 51 & 19 \\
\hline Tertiary/university & 31 & 11.6 \\
\hline \multicolumn{3}{|l|}{ Husband's educational status ( $\mathrm{n}=267)$} \\
\hline Uneducated & 14 & 5.7 \\
\hline Primary school & 109 & 44.1 \\
\hline High school & 61 & 24.7 \\
\hline University & 63 & 25.5 \\
\hline \multicolumn{3}{|l|}{ Marital status (n=268) } \\
\hline Married & 230 & 85.8 \\
\hline Single & 38 & 14.2 \\
\hline \multicolumn{3}{|l|}{ Employment status ( $\mathrm{n}=268)$} \\
\hline Housewife & 186 & 69.4 \\
\hline Employed & 30 & 11.2 \\
\hline Retired & 52 & 19.4 \\
\hline \multicolumn{3}{|l|}{ Economic status $(\mathrm{n}=268)$} \\
\hline Income is more than expenditure & 28 & 10.4 \\
\hline Income is equal to expenditure & 152 & 56.7 \\
\hline Income is less than expenditure & 88 & 32.8 \\
\hline \multicolumn{3}{|l|}{ Body mass index (BMI) $(n=240)$} \\
\hline 20-24.9 (Normal) & 59 & 24.6 \\
\hline 25-29.9 (Overweight) & 103 & 42.9 \\
\hline$>29.9$ (Obese) & 78 & 32.5 \\
\hline \multicolumn{3}{|c|}{ Participation in decision-making in family $(n=268)$} \\
\hline Yes & 225 & 84.0 \\
\hline No & 43 & 16.0 \\
\hline \multicolumn{3}{|c|}{ Medical problem necessitating medication $(n=268)$} \\
\hline No & 110 & 41.1 \\
\hline Yes & 158 & 58.9 \\
\hline \multicolumn{3}{|l|}{ Smoking } \\
\hline Never & 216 & 80.6 \\
\hline Smoker (current/past) & 52 & 19.4 \\
\hline
\end{tabular}


Table 2. Gynecological characteristics of the cases

\begin{tabular}{lcc}
\hline \multicolumn{3}{c}{ Mean $( \pm \mathrm{SD})$} \\
\hline Parity & $3.9( \pm 1.9)$ \\
Age at the marriage $(\mathrm{n}=267)$ & $20.2( \pm 3.9)$ & $\%$ \\
Menopausal status $(\mathrm{n}=268)$ & $\mathrm{n}$ & 34.7 \\
$\quad$ perimenopause & 93 & 48.9 \\
$\quad$ natural menopause & 131 & 16.4 \\
$\quad$ surgical menopause & 44 & \\
Menopausal age (natural menopause) & (Range: $34-57)$ \\
(n=131) & $46.5( \pm 4.8)$ \\
Menopausal age (surgical menopause) & \\
$(\mathrm{n}=44)$ & $45.1( \pm 4.9)$ & (Range:36-55) \\
\hline
\end{tabular}

MRS consists of 11 domains, and each domain has options as "no (0)", "minimal (1)", "moderate (2)" and "severe (3)". To simplify, if someone has high points, this shows that this woman has more complaints, and as a consequence, symptoms have negative impact on the quality of life. Validity and reliability of the scales are important in different sociocultural populations. The validation of MRS was performed in Turkey in 2005. ${ }^{[4]}$

\section{The World Health Organization Quality of Life Instrument (WHOQOL-BREF-TR) Questionnaire}

The WHOQOL questionnaire let us evaluate both the quality of life and also the condition of health. WHOQOLBREF, a shortened form of the WHOQOL-100, contains four domains and 26 questions. ${ }^{[5]}$ WHOQOL-BREF in Turkish was validated in $1999{ }^{[6]}$ This scale is a Likert-type scale which is easy to complete. Turkish version of WHOOQOLBREF has an additional 27th question. This question is called "national environment domain (Domain 5)" and it evaluates social pressure on that particular person.

To simplify, in WHOQOL-BREF questionnaire, the higher the points someone gets, the better the quality of life he/she has.

\section{Statistical Analysis}

We used SPSS software (SSPS, Chicago, IL, Version 11,5) for statistical analysis. T-test, ANOVA, Kruskal-Wallis test, correlation analysis and percent distribution were used when appropriate. Mean values were presented as mean \pm SD (standard deviation). A p value of less than 0.05 was considered statistically significant. Since some of the questions were not answered by all participants, actual
Table 3. Menopausal knowledge of the women

\begin{tabular}{lcc}
\hline & $\mathrm{n}$ & $\%$ \\
\hline Any knowledge on menopause? & & \\
$\quad$ Yes & 81 & 30.2 \\
No & 77 & 28.7 \\
Partial & 110 & 41.1 \\
The source of information on menopause & & \\
Physician & 74 & 27.6 \\
TV-radio-internet & 71 & 26.5 \\
Neighbours-Relatives & 55 & 20.5 \\
Books-Magazines-Newspaper & 45 & 16.8 \\
Midwife/nurse & 25 & 9.3 \\
Friends & 18 & 6.7 \\
\hline
\end{tabular}

* more than one option could be marked.

numbers are always presented in the results section and taken into the consideration during the statistical analysis.

\section{RESULTS}

Table 1 shows the characteristics of the women in this study. Almost $1 / 5$ of the cases had no formal education, whereas the percentage of uneducated husbands is lesser. Most of the women $(69.4 \%)$ in our study group were housewives. Among the women who answered the question about BMI, most $(75.4 \%)$ were overweight or obese. Some women $(16 \%)$ do not participate in decision-making process in their families. More than half of all women had some health problems necessitating medication. Of all, only 52 women $(19.4 \%)$ were current smokers.

Gynecological characteristics of the women are presented in Table 2. Age at natural menopause was $46.5 \pm 4.8$ years.

One of the results in our questionnaire was about "menopausal knowledge" (Table 3). Almost $1 / 3$ of women had no knowledge on menopause. Slightly higher than $1 / 3$ of women had the chance of having menopausal knowledge from their health care providers (physicians, nurses, midwives). Although data are not shown here, $77 \%$ thought that the information that they had been given by health care providers was sufficient.

When we analyzed the relationship between the MRS scores and WHOQOL-BREF-TR scores, we found weak inverse correlation between the MRS scores and three domains of QOL scores (physical health $\mathrm{r}=-0.205$ $\mathrm{p}=0.001$, physical well-being $\mathrm{r}=-0.215 \mathrm{p} \mathrm{p}<0.001$, social

Table 4. The relationship between the mean MRS scores and quality of health scores (according to the different domains) (statistical differences are highlighted)

\begin{tabular}{cccccc}
\hline & Physical health & $\begin{array}{c}\text { Psychological } \\
\text { well-being }\end{array}$ & Social relationship & $\begin{array}{c}\text { Satisfaction with } \\
\text { the environment }\end{array}$ & $\begin{array}{c}\text { Relationship with } \\
\text { close environment }\end{array}$ \\
\hline Mean MRS score & $\mathrm{r}=-0.205$ & $\mathrm{r}=-0.215$ & $\mathrm{r}=-0.198$ & $\mathrm{r}=-0.034$ & $\mathrm{r}=-0.037$ \\
$\mathrm{p}=0.001$ & $\mathrm{p}<0.001$ & $\mathrm{p}=0.001$ & $\mathrm{p}=0.579$ & $\mathrm{p}=0.548$ \\
\hline
\end{tabular}


Table 5. The relationship between the demographic data and the mean MRS scores/QOL scores (statistical significant differences are highlighted)

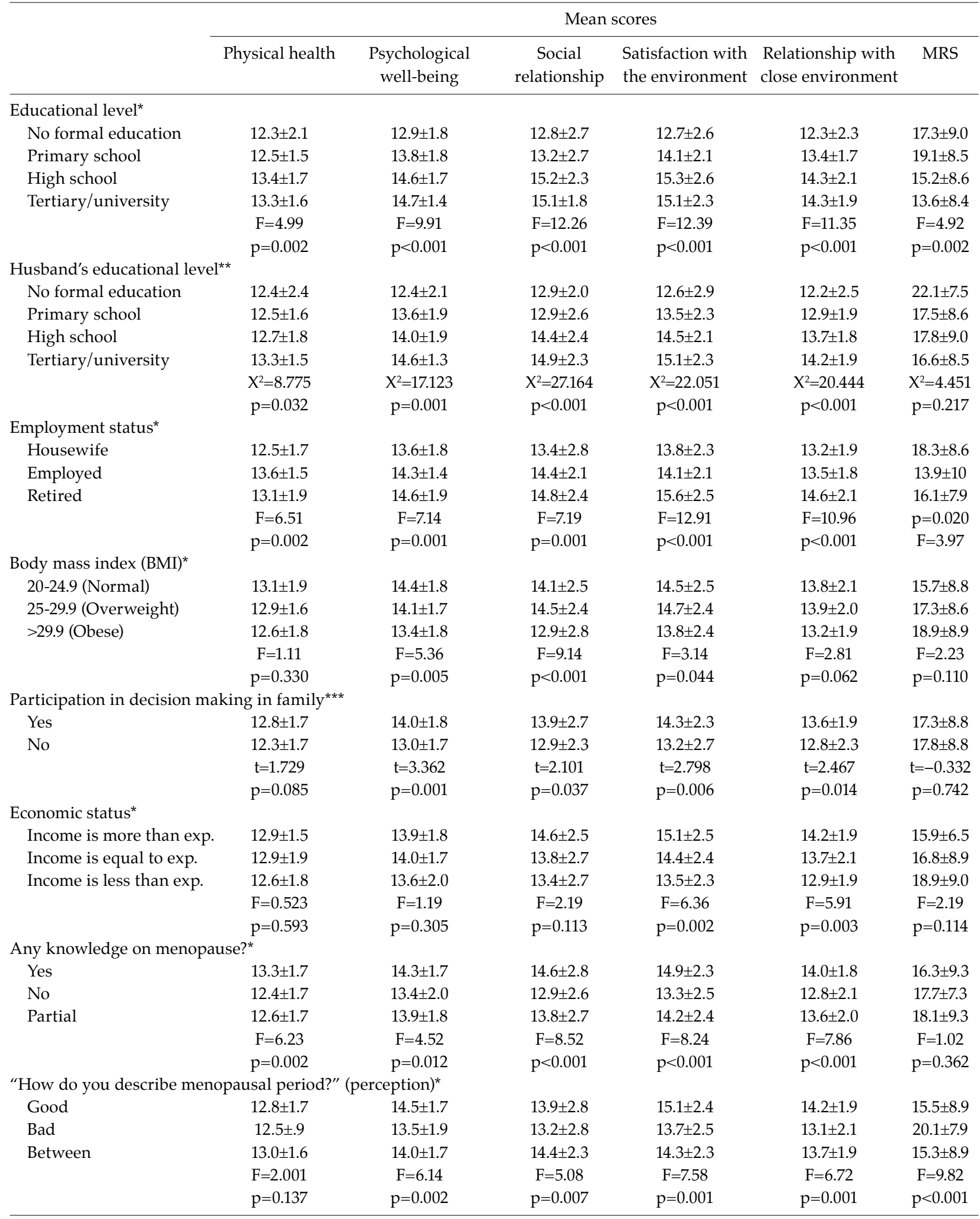

*One-way ANOVA; **Kruskal-Wallis test; ${ }^{* *}$ Independent samples test; exp: expenditure. 
Table 6. Correlation between demographic characteristics and MRS scores (statistical significant differences are highlighted)

\begin{tabular}{|c|c|c|}
\hline Demographic characteristics & $\mathrm{n}$ & MRS scores \\
\hline \multicolumn{3}{|l|}{ Age $^{*}$} \\
\hline $40-47$ & 83 & $15.2 \pm 8.8$ \\
\hline $48-55$ & 132 & $18.7 \pm 8.7$ \\
\hline \multirow[t]{2}{*}{$>55$} & 53 & $17.6 \pm 8.5$ \\
\hline & & $\mathrm{F}=4.24 \mathrm{p}=0.015$ \\
\hline \multicolumn{3}{|l|}{ Marital status ${ }^{* *}$} \\
\hline Married & 230 & $17.9 \pm 8.6$ \\
\hline \multirow[t]{2}{*}{ Single } & 38 & $13.9 \pm 8.9$ \\
\hline & & $\mathrm{p}=0.013$ \\
\hline \multicolumn{3}{|l|}{ Menopausal status* } \\
\hline Perimenopause & 93 & $15.3 \pm 9.1$ \\
\hline Natural menopause & 131 & $18.5 \pm 8.5$ \\
\hline \multirow[t]{2}{*}{ Surgical menopause } & 44 & $18.5 \pm 8.3$ \\
\hline & & $\mathrm{F}=4.11 \mathrm{p}=0.017$ \\
\hline \multicolumn{3}{|l|}{ Marital age (years) $(n=267)^{*}$} \\
\hline $2-20$ & 36 & $14.9 \pm 8.9$ \\
\hline $21-30$ & 121 & $16.2 \pm 8.4$ \\
\hline \multirow[t]{2}{*}{$31-49$} & 112 & $19.7 \pm 8.7$ \\
\hline & & $\mathrm{F}=6.73 \mathrm{p}=0.001$ \\
\hline \multicolumn{3}{|c|}{ Medical problem necessitating medication ${ }^{* *}$} \\
\hline No & 110 & $14.9 \pm 8.2$ \\
\hline \multirow[t]{2}{*}{ Yes } & 158 & $19.2 \pm 8.8$ \\
\hline & & $\mathrm{P}<0.001$ \\
\hline
\end{tabular}

*One-way ANOVA; **Independent samples test (t-test).

relationship $\mathrm{r}=-0.198 \mathrm{p}=0.001$ ). This means that the higher the MRS scores were, the worse the quality of life for those three domains was (Table 4).

Table 5 shows the relationship between the demographic data and the mean MRS scores/QOL scores. As shown, educational status of the women was significantly influenced both MRS scores and QOL scores positively (physical health $\mathrm{p}=0.002$, physical well-being $p<0.001$, social relationship $p<0.001$, satisfaction with the environment $p<0.001$, relationship with close environment $p<0.001$ and MRS $p=0.002$ ). This means that the higher the educational level the better the quality of life and the lesser the menopausal complaints. Educational status of the husbands also affected the quality of health scores of the women in positive manner.

Body mass indices significantly influenced some domains of the quality of life scores (psychological wellbeing $p=0.005$, social relationship $p<0.001$, satisfaction with the environment $p=0.044$ ). This means that if the BMI increases, the quality of life scores of those domains decrease.

There was a statistically significant difference between the participation in decision-making in the family and some domains of quality of life scores (psychological well-being $p=0.001$, social relationship $p=0.037$, satisfaction with the environment $p=0.006$, the relationship with close environment $p=0.014$ ). This means that in women participating in decision-making in their families, quality of life scores are higher in these domains. However, there was no difference between the participation of decisionmaking in the family and MRS scores.

Economical status did not affect MRS scores, however, it affected environmental domains of QOL scores significantly (satisfaction with the environment $\mathrm{p}=0.002$, the relationship with close environment $\mathrm{p}=0.003$ ).

There was also a statistically significant difference between the QOL scores and menopausal knowledge (physical health $\mathrm{p}=0.002$, physical well-being $\mathrm{p}=0.012$, social relationship $p<0.001$, satisfaction with the environment $p<0.001$, relationship with close environment $\mathrm{p}<0.001)$. However, there was no difference between menopausal knowledge and MRS scores.

Table 6 shows the correlations between some demographic data and MRS scores. According to this study, the worst MRS scores were obtained from perimenopausal married women at an age range of 48 to 55 and with having health problems necessitating medication.

\section{DISCUSSION}

Climacteric period and menopause are important for women in terms of problems such as hot flushes, sleeplessness, vaginal atrophy, and also some long-term consequences such as osteoporosis, increasing risks of heart problems. These problems may affect the quality of life of a woman. Cultural differences may play an important role in the perception of the symptoms and affect the quality of life..$^{[7,8]}$ There have been lots of studies regarding the quality of life and climacterium, although there is not a certain consensus. ${ }^{[9-1]}$ Certainly, there are many factors affecting the quality of life of women during that period.

First of all, there is a supplementary finding in our study. One third of women in our study have no knowledge on menopause. According to our data, media and friends are still important sources of menopausal knowledge in our study population. This may easily explain the low hormonal therapy rates despite existing symptoms in our population. An additional important finding in this study is that women who have knowledge on menopause have higher quality of life than who does not have menopausal knowledge. Thus, if we convey enough knowledge on menopause we may increase the quality life.

We found that the MRS scores had strong negative impact on some domains of quality of life. These domains are physical health, physical well-being and social relationship. It is important to note that although all women in the study were symptomatic, when the severity of symptoms was increased above-mentioned three domains of quality of life were decreased. Thus, we may say that severity of symptoms inversely correlate with the quality of life. 
However, environmental and close environmental relationship were not affected by MRS scores. Our findings are in accordance with many previous studies and confirm negative effects of menopause on quality of life. . $^{[12,13]}$

We found that educational level of the women had positive impact on menopausal symptoms. We may interpret this as follows; if a woman is educated, she can cope better with menopausal symptoms. Our finding is in conformity with the studies performed on the same as well as the other cultural groups in terms of the effect of educational level on menopausal symptoms. ${ }^{[14,15]}$

We know that menopause itself may cause weight gain and a shift in the distribution of fat. ${ }^{[16]}$ Although some women in this study did not answer the question about BMI, among those who answered, only $1 / 4$ had normal BMI and the rest were either overweight or obese. Additional explanation for high BMI values may be that women in our region are mostly housewives; they have more sedentary life compared with "working" women. Although some clinical literature proposed that menopausal symptoms might decrease owing to the production of estrone in adipose tissue, ${ }^{[17]}$ we have found that high BMI had negative impact on some domains of quality of life, but not on the MRS scores. These domains are psychological well-being, social relationship and satisfaction with the environment. Obviously, obesity is a silent epidemic not only in postmenopausal women but in all over the world. A recent study showed a positive association between somatic and psychological dimensions of health-related quality of life and participation in regular exercise. ${ }^{[18]}$ Longitudinal studies may add further information on this important issue.

In this study, we did not aim to investigate the effect of hormonal therapy on postmenopausal quality of life. However, since we have found that the severity of symptoms inversely correlate with the quality of life, we believe that hormonal therapy (estrogen/estrogen plus progestin), which deals with the postmenopausal symptoms perfectly, would increase the quality of life in postmenopausal women as indicated by many authors previously. ${ }^{[1,19]}$

We found positive impact of economic status on some domains of quality of life. These domains were satisfaction with the environment and relationship with close environment.

Certain limitations should be considered in our study. Cause and effect relations are difficult to asses in such cross-sectional studies. We have not divided as peri- and postmenopausal groups. However, all women were symptomatic in this study. Future longitudinal studies may shed a light on exact cause-effect relations.

In conclusion, the severity of menopausal symptoms inversely correlates with quality of life of climacteric women. In climacteric women, we may increase quality of life by increasing their education level and menopausal knowledge, helping them loose weight, and also by decreasing the menopausal symptoms.

\section{REFERENCES}

1. Utian WH. Quality of life (QOL) in menopause. Maturitas 2007;57:100-2.

2. Hauser GA, Huber IC, Keller PJ, Lauritzen C, Schneider HPG. Evaluation of climacteric symptoms (Menopause Rating Scale) Zentralbl Gynakol 1994;116:16-23. [Abstract]

3. Potthoff P, Heinemann LA, Schneider HP, Rosemeier HP, Hauser GA. The Menopause Rating Scale (MRS II): methodological standardization in the German population. Zentralbl Gynakol 2000;122:280-6. [Abstract]

4. Gürkan ÖC. Menopoz semptomları değerlendirme ölçeğinin Türkçe formunun güvenirlik ve geçerliliği. Hemşirelik Forumu Dergisi 2005;3:30-5.

5. Development of the World Health Organization WHOQOLBREF quality of life assessment. The WHOQOL Group. Psychol Med 1998;28:551-8.

6. Eser E, Fidaner H, Fidaner C, Eser SY, Elbi H, Göker E. WHOQOL-100 ve WHOQOL-BREF'in psikometrik özellikleri. 3P Dergisi 1999;7:23-40.

7. Sommer B, Avis N, Meyer P, Ory M, Madden T, KagawaSinger $\mathrm{M}$, et al. Attitudes toward menopause and aging across ethnic/racial groups. Psychosom Med 1999;61:868-75.

8. Avis NE, Stellato R, Crawford S, Bromberger J, Ganz P, Cain $\mathrm{V}$, et al. Is there a menopausal syndrome? Menopausal status and symptoms across racial/ethnic groups. Soc Sci Med 2001;52:345-56.

9. Budakoğlu II, Ozcan C, Eroğlu D, Yanik F. Quality of life and postmenopausal symptoms among women in a rural district of the capital city of Turkey. Gynecol Endocrinol 2007;23:404-9.

10. Ozkan S, Alataș ES, Zencir M. Women's quality of life in the premenopausal and postmenopausal periods. Qual Life Res 2005;14:1795-801.

11. Avis NE, Assmann SF, Kravitz HM, Ganz PA, Ory M. Quality of life in diverse groups of midlife women: assessing the influence of menopause, health status and psychosocial and demographic factors. Qual Life Res 2004;13:933-46.

12. Blumel JE, Castelo-Branco C, Binfa L, Gramegna G, Tacla $X$, Aracena $B$, et al. Quality of life after the menopause: a population study. Maturitas 2000;34:17-23.

13. Jacobs PA, Hyland ME, Ley A. Self-rated menopausal status and quality of life in women aged 40-63 years. Br J Health Psychol 2000;5:395-411.

14. Uncu Y, Alper Z, Ozdemir H, Bilgel N, Uncu G. The perception of menopause and hormone therapy among women in Turkey. Climacteric 2007;10:63-71.

15. Li C, Samsioe G, Borgfeldt C, Lidfeldt J, Agardh CD, Nerbrand C. Menopause-related symptoms: what are the background factors? A prospective population-based cohort study of Swedish women (The Women's Health in Lund Area study). Am J Obstet Gynecol 2003;189:1646-53.

16. Sturdee DW, MacLennan AH. The weight problem. Climacteric 2007;10:83-4.

17. Erickson GF. Ovarian anatomy and physiology. In: Lobo RA, Kelsey J, Marcus R, editors. Menopause: biology and pathobiology. San Diego, CA: Academic Press; 2000. p. 13-32.

18. Daley A, Macarthur C, Stokes-Lampard H, McManus R, Wilson S, Mutrie N. Exercise participation, body mass index, and health-related quality of life in women of menopausal age. Br J Gen Pract 2007;57:130-5.

19. Welton AJ, Vickers MR, Kim J, Ford D, Lawton BA, MacLennan $\mathrm{AH}$, et al. Health related quality of life after combined hormone replacement therapy: randomised controlled trial. BMJ 2008;337:a1190. 